\section{Bruk av hjertesviktpacemaker i Europa}

\author{
En europeisk multisenterstudie viser at behandling med implantasjon \\ av hjertesviktpacemaker kan være nyttig for flere pasientgrupper enn \\ tidligere antatt.
}

Pasienter med hjertesvikt har ofte en skade $\mathrm{i}$ hjertets ledningssystem. Dette kan føre til redusert pumpekraft på grunn av ukoordinert sammentrekning, noe som kan behandles med en hjertesviktpacemaker (kardial resynkroniserende behandling, CRT).

- Dagens behandlingsstrategi er basert på store internasjonale forskningsstudier, men anvendelsen av hjertesviktpacemaker utenfor studiene har ikke vært kartlagt. Bruken varierer fra land til land, og det er en stor utfordring å forhåndsdefinere pasientgrupper som kan ha nytte av behandlingen, sier Nigussie Bogale.

Han har tatt doktorgraden på en studie igangsatt i regi av de europeiske hjertesviktog hjerterytmeforeningene for å evaluere praksis ved implantering av hjertesviktpacemaker. Studien omfatter 2438 pasienter fra 141 sentre i 13 land.

- Studien viser at sentre med høyt antall behandlinger ofte er mer utforskende med henblikk på indikasjoner: De implanterer oftere hjertesviktpacemaker hos eldre pa- sienter, det vil si personer over 75 år, ved mildere symptomer, som forkammerflimmer eller QRS-bredde $<120$ millisekunder, og hos pasienter som tidligere har fått vanlig pacemaker, sier Bogale.

Ett års oppfølgingsdata viste at de fleste pasientene følte seg mye bedre etter implantasjon av hjertesviktpacemaker, og at antall dødsfall og sykehusinnleggelser var sammenliknbare med funn fra tidligere studier. Det var ingen forskjeller i utfall eller grad av komplikasjoner mellom pasienter som ble oppgradert fra vanlig pacemaker til hjertesviktpacemaker og pasienter som fikk implantert hjertesviktpacemaker for første gang.

- Dette er en prospektiv observasjonsstudie av vellykkede hjertesviktpacemakerbehandlinger, så resultatene må tolkes med forsiktighet, sier Bogale.

\section{Anne Forus}

anneforus@hotmail.com

Tidsskriftet

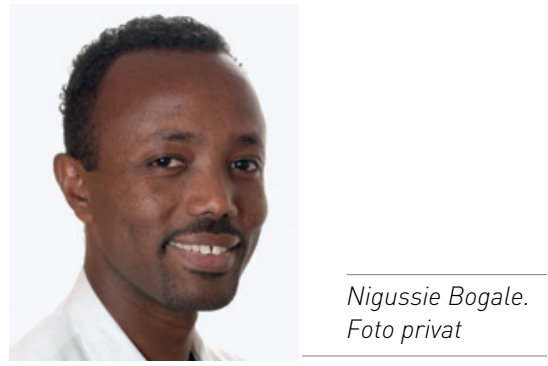

Disputas

Nigussie Bogale disputerte for ph.d-graden ved Universitetet i Bergen 20.10. 2011. Tittel på avhandlingen er European Cardiac Resynchronization Therapy (CRT) Survey.

Ordforklaring

QRS-bredde: Mål for varighet av elektrisk impuls.

\title{
Godartet multippel sklerose
}

\section{Multippel sklerose kan arte seg svært forskjellig. Noen pasienter har ingen eller få symptomer selv etter mangeårig sykdom, og forløpet kalles da godartet multippel sklerose.}

Multippel sklerose (MS) er en kronisk betennelsessykdom i sentralnervesystemet som oftest rammer unge voksne. Noen pasienter kan ha minimale symptomer, andre vil oppleve et mer invalidiserende forløp. Solveig Bergliot Glads avhandling er en studie av hovedsakelig pasienter med godartet multippel sklerose etter gjennomsnittlig over 20 års oppfølging.

- Hovedresultatene viser at godartet multippel sklerose over tid kan utvikle seg til et mindre godartet forløp. Faktorer som kjønn (kvinne), ung alder og et attakkvis forløp ved sykdomsdebut, i tillegg til få årlige attaker, er prognostiske faktorer for et mer godartet forløp. Imidlertid kan disse faktorene bare forklare en mindre prosentdel av hvorfor disse pasientene hadde godartet sykdom, sier spesialist i nevrologi, Solveig Bergliot Glad.

Hele $65 \%$ av dem med godartet multippel sklerose var fortsatt $i$ arbeid etter over 20 års sykdom, mens flesteparten av dem med ikke-godartet multippel sklerose hadde falt ut av arbeidslivet.

- Sykdomsforløpet kan altså variere, noe studien viser. Ca. $27 \%$ av pasientene kan oppleve en godartet form av sykdommen med begrenset funksjonssvikt. Vi inkluderte i stor grad pasienter som ikke hadde fătt eller hadde startet sent med sykdomsmodifiserende medisiner. Sykdomsforløpet for dem som får multippel sklerose i dag, antas å være bedre enn det var før, ettersom behandlingsmulighetene blir stadig bedre. $\mathrm{Vi}$ har forsøkt å belyse det økende behovet for gode prognostiske biologiske markører som kan predikere sykdomsforløpet hos den enkelte, for å kunne skreddersy multippel sklerose-behandlingen bedre enn det som er mulig i dag, sier Glad.

\section{Tone Bergset}

tone.bergset@legeforeningen.no

Tidsskriftet

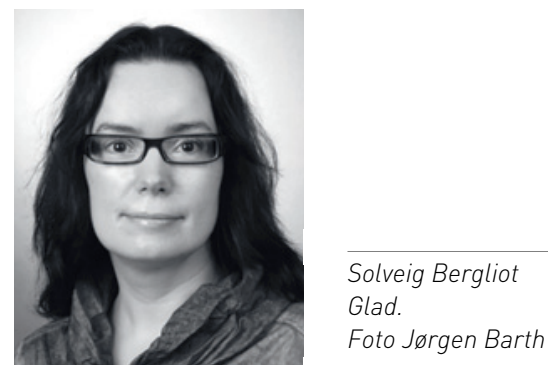

Disputas

Solveig Bergliot Glad disputerte for ph.d.graden ved Universitetet i Bergen 18.11. 2011 med avhandlingen Det naturlige forløp ved godartet (benign) multippel sklerose. Resultater fra en populasjonsbasert langtidsoppfølging av multippel sklerose $i$ Hordaland. 